\title{
Coronavirus and Changing Human Attitudes and Behaviors
}

\author{
Saeid Abdolmalaki \\ The Department of Psychology, Payame Noor University, Tehran, Iran \\ Email: s_abdolmalaki@yahoo.com
}

How to cite this paper: Abdolmalaki, S. (2022). Coronavirus and Changing Human Attitudes and Behaviors. Open Journal of Social Sciences, 10, 1-13.

https://doi.org/10.4236/jss.2022.103001

Received: January 14, 2022

Accepted: February 27, 2022

Published: March 2, 2022

Copyright (C) 2022 by author(s) and Scientific Research Publishing Inc. This work is licensed under the Creative Commons Attribution International License (CC BY 4.0).

http://creativecommons.org/licenses/by/4.0/

\begin{abstract}
The Covid-19 pandemic has posed an ontological challenge to mankind. It has caused many economic, social and psychological damages that will not be compensated for many years. Not only do the masses wander in purgatory, but scientists, philosophers, and intellectuals are confused and in a cognitive crisis. Man is constantly asking himself what has happened to him? And what will the future be like? It is not easy to find convincing answers to such important questions. However, speculative and probabilistic answers can also be a source of strength for the current afflicted person. Now that the corona is still in place, it is not possible to give an accurate estimate of the extent of its damage, perhaps an accurate assessment can be made in the post-corona. The fact is that Corona has staged coups against human societies and caused countless economic, social and psychological crises and damage to governments and nations. Currently, social harms as a super-crisis are due to a quarantined lifestyle and lack of research and planning like an iceberg, the first of which is feasibility. Thus, the real harm will come when the vaccination process ends and the collective actions and activities begin. Then we will face the avalanche of social harms that we need to plan and policy from now on. In this article, an attempt has been made to study and critically analyze the economic, social and behavioral changes resulting from the Corona pandemic with an interdisciplinary approach and to show a perspective on the future of the post-corona.
\end{abstract}

\section{Keywords}

Coronavirus, Psychological Analysis, Attitude Change, Social Harms, Post-Covid

\section{Introduction}

The experience of living in a corona has raised countless questions in the minds 
of human societies. Including: Where did Corona come from? What has Corona done to us? How will the post-corona world be global? How does the interaction of governments and nations take shape? What will democracy, freedom and human rights change? What will human economic behavior be like? What is the position of science? What will happen to man's religious beliefs, more religious or atheist? What is the mechanism of adaptation to the new lifestyle? Will man maintain his former relationships or will he inevitably put a review of his beliefs, behaviors, and relationships on the agenda? How will politics and international relations be implemented? And thousands of other micro-questions.

The Wikipedia encyclopedia defines a coup as "the sudden and violent overthrow of a state or government by a small group". During the coup, in the first step, the armed forces are disarmed. If we consider doctors and scientists as the armed forces of a country and their science as a weapon, we must admit that the Covid-19 pandemic is more than a common disease and has staged a coup against humanity and disarmed it.

The Covid-19 pandemic was a soft overthrow and a creeping coup against human authority over the universe. No war and violence, even firing a bullet and wasting a drop of blood, he was able to handcuff humans. The epidemic was a coup against the blind, dark and unbridled instincts of mankind. All powers, large and small, politicians and ordinary people, have all been disarmed. Ambition, false pride, the struggle for survival and the operation of the evil idea: "Man is a wolf is man", has turned our world into a black hole for the weak and the poor and a paradise for criminals. Yes, politicians can no longer be seen as rivals, as Corona has disabled the gears of its government. Singers do not have pride and intoxication. Why so, unkind compromise plays. Millions of stubborn people do not play the trumpet in sports stadiums. Why so, it is not going to be held anymore. Prostitutes, pubs, casinos, human traffickers, porn filmmakers and drug traffickers have been shut down until further notice and at an unknown time (Abdolmalaki, 2021).

\section{Attack of Psychological and Social Injuries}

Increased suicide due to deadlock, the virus has been particularly prevalent since the early days of individuals and communities with low psychological capital and spiritual health. In such a slice of life, having a purpose and meaning to live, it is more obligatory than dinner. The turbulent association of the World War I market, the Nazi concentration camps, and Victor Frankl has engulfed the human mind plagued by the Covid-19 pandemic. In the words of Nietzsche: "One who has found the reason for life; "He will build in any way". If we reach this stage of greatness where the suffering we are suffering now is not from an evil force and has come to help us find ourselves. To discover more the dark and light aspects of our existence and to enrich our lives more deeply, we will not experience philosophical despair, nor will we be motivated to commit suicide.

Each of us urgently needs a psychological defense mechanism to support us 
and rationalize sudden crises for us. The experience of illness, floods, earthquakes, accidents and the death of loved ones is tolerable when we find a convincing reason for ourselves, otherwise we will suffer a psychological collapse. From the first weeks of the pandemic, two Italian female nurses committed suicide for fear of contracting the Coronavirus. Other series of suicides were reported from around the world. The inability to find meaning to live in such a turbulent world will result in countless long-term depression, helplessness, and suicide.

To relieve anxiety and alleviate this psychological pain, a significant portion of the people in the community has resorted to the unusual use of drugs and alcohol.

Decreased tolerance of family members, especially couples who are emotionally cold between them-due to long-term quarantine, has led to horrific divorce statistics. Following the divorce of a New York couple, an astonishing phenomenon called the "covidivorce" took shape. The long queue of divorce applicants after the end of quarantine in China has come as a surprise and a serious global concern. The recession, unemployment, and inability to support ourselves have put the foundation of the family at risk of collapse. In the meantime, prostitution, begging, increasing numbers of working children, child abuse, poverty, homelessness, violence against women, petty thefts and domestic murders are some of the abnormal behaviors that many human societies have reported experiencing.

Domestic violence against women has increased many times during the quarantine period. China, Italy and Turkey are the three countries that have published reports of domestic violence against women. China reported 162 cases in February 2020, an increase of almost three and a half times compared to the same situation in 2019 (Shabani, 2020). This led to an increase in the number of divorce applications after the quarantine was lifted.

The World Health Organization has warned of domestic violence against women. Violence against women, it has irreparable destructive effects on the body of the family and society. Causes various types of psychosis such as insecure attachment, separation anxiety, depression, morbid fears and autism in children.

A Canadian mother who lost her husband in a sudden death in 2019 and now, in addition to being responsible for the family income, is also in charge of housework and raising two children, says in an interview with the New Yorker. The pressure and juggling of other things has become unbearable for him: "It has become difficult for me to do my job, to be a cook and a teacher at the same time, and finally to make time for myself. Some days I feel like I'm sinking" (Babroo, 2020). This sense of drowning and drowning is an example of the lived experience of millions and perhaps billions of people living on the planet who bear the pain of the Covid-19 pandemic wholeheartedly. In the meantime, women suffer more.

The most immediate effect of the Covid-19 pandemic. It was a psychological 
shock. Something like a birthmark, for a baby who is torn from the mother's womb and thrown out. The media turned this shock into a global earthquake. At first only China was involved, the world news media portrayed it as if a cannibalistic monster had fallen on humanity and would soon devour everyone. This complex, mysterious and unknown creature created such horror in human beings that everyone was waiting for death. Initially, only a handful of countries and communities were involved; the number of casualties was higher than the number of casualties. Unfortunately, the panic caused by the lack of human readiness to face the pandemic was greater than the destructive and crippling virus itself.

Covid-19 has caused a cognitive-behavioral shock to humans due to its speed of dissemination and unknown identity. Without any doubt, Post-Crown man will experience years of mental and behavioral instability and suffer from a variety of nightmares. Psychotic experience: types of phobias, fear of death, fear of strangers, fear of loneliness, fear of public places, such as; Markets, parties, gatherings, travel, shopping malls and even going out. Also, obsessive-compulsive disorders such as; Repeated behavior of repeated washing of hands and face and repetitive thoughts such as: Constantly thinking about suffering and death. Also, experience depression due to unfinished grief and unexpressed excitement over the death of loved ones who fell ill in the blink of an eye and were embraced by the angel of death. Feelings of loneliness, feelings of failure, hopelessness, and negative attitudes toward the future have plunged societies into mass depression. Choosing depression is perhaps the best and wisest human response to such a filthy situation. Also, sleep disorders and coronary nightmares; many referrals to counseling centers as well as ordinary people suffer from dreaming of monsters, wolves, dinosaurs and insect attacks. Also, eating disorders; nervousness and obesity due to quarantine and inactivity, as well as nervousness due to fear of transmitting the virus to the body through food and drink. Also, obsession with shopping; many of us have pathological behaviors about buying certain items and necessities especially; we have toiletries, detergents, masks and gloves; repetitive behaviors that are sometimes unreasonable and annoying.

Humans have experienced countless psychological traumas throughout history. At every point in history a calamity has befallen him. The cause and source of some of these disasters has been itself. From the very beginning of creation, he was expelled from heaven for his disobedience and rebellion. Heavy costs have been paid for this rebellion to date. Power, status, and worship are adorable to him, and what wars and massacres he has not waged to seize them. The braking of this occasional extravagance by the wrath of the living world floods and earthquakes to a variety of diseases. But greedy human beings do not give up.

The psychosis caused by Covid-19 is serious. Mental health, physical health and economics are interrelated. Decreased mental health has a direct effect on physical health. Followed by, reducing the labor market and putting pressure on the economy and reducing the GDP is inevitable. 
Social isolation, loneliness, fear, insecurity, drug and alcohol addiction, failure in interpersonal relationships, anxiety, depression and suicide; Among the mental health crises are not only the countries involved in the pandemic; Rather, communities that have not yet had the honor of hosting Quidd and are merely watching the catastrophe through television or social media; Threatens.

UN experts have warned that in this case; Children and adolescents are the most vulnerable groups in society. One of the best solutions in this situation is to be realistic and ready to accept change, especially change in social relations. Covid-19 may never go away and last as long as the flu and AIDS. We must acquire the necessary skills to coexist with it. On the other hand; Governments need to invest heavily in developing mental health services and increasing mental health resources.

The next step for governments can be the psychological empowerment of people in their community. Strengthen the psychological foundations of society dramatically the power of initiative, creativity, innovation, resilience and problem solving and most importantly; It increases accountability, and individuals in society offer new and responsible solutions to economic and social problems, and in practice, the government's overload is reduced.

The results of a survey in the UK show that the level of anxiety and panic about mental disorders caused by the Covid-19 pandemic has increased. also; Twenty mental health experts, including psychiatrists, psychologists, and psychiatrists, have warned of the dire consequences of coronary heart disease and its impact on mental health, calling for the government to prioritize psychological research (https://www.independentpersian.com/, 16 April 2020). A survey by the Ipsus Murray Institute of 1099 Britons found that quarantine had a negative effect on their mental health and that more than half of them had experienced anxiety disorder.

A pandemic has raised the global paranoia index. The illusion of conspiracy and collective suspicion runs rampant among societies and nations. The cracking of the schema of trust in the human mind has cast doubt on the rational reasoning and intelligence of human beings. The UN Secretary-General referred to this morbid situation as "a tsunami of hatred and xenophobia, blaming others and creating panic" (https://www.un.org/press/en/2020/sgsm20076.doc.htm) Is. Although Guterres has blamed Muslims, immigrants and the elderly for the victims of this hatred and conspiracy delusion, but; In American public opinion, the Chinese are the main culprits of the pandemic. It has even been observed that in public places and shops, people quarrel with the Chinese and vent their anger and concern over them.

Adopting social isolation as a defense mechanism against the fear of strangers has become part of the lifestyle for many individuals and communities because they view others as a source of threat and danger.

\section{Changing Attitudes towards Life}

The Covid-19 pandemic has put humans in a state of childbirth. Childbirth in 
thought, attitude and lifestyle. The virus progresses to the point where a new human being is born that is fundamentally different from the classic version.

Covid's sudden surprise; It disrupted the attitudes and decisions of all of us. But now this mental turmoil has moved away from the state of crisis and has reached the stage of evaluation. In our knowledge, belief in change has become a movement. Although some of us are still in shock and what to do, most of us have found our stability and are studying and planning for the post-Corona era. What did you see of God; perhaps on a hearty morning not far away, the TV presenter announces the disappearance of this uninvited guest and surprises us all; leave a tear behind; we stay and the whole nostalgic memory is more bitter and less sweet.

Anyway, reference to the true essence and meaning of life has begun. Instead of paying attention to luxury and ornamental brands and brands and pretending to be worthy, people should strengthen their immune system, increase psychological capital, such as: Resilience and hope have risen. Physical and mental health is more important than new clothes and makeup. Dramatic behaviors, eye-popping, pride, boasting and gaining approval from others, have lost their meaning.

Human tastes have shifted from entertainment to health and safety. The entertainment-oriented and relaxed society has become a health-oriented, bodycentered and concerned society. Focus is on the outside. Others; Even spouses, children, and parents are sometimes left out of the first priority. Keeping your body and mind focused on yourself is the basis of your concerns. The worry of life and death is more serious than ever. Everyone spends a lot of time searching for medical, health, nutrition and psychological services online. Sports stadiums, cinemas, concerts and even trips far and near have been moved to the realm of the mind.

In an open letter, 200 scientists, Nobel Prize winners and movie stars, including Cate Blanchett, Robert De Niro, Jane Fonda and Monica Bellucci, called for fundamental changes in the post-Corona human lifestyle. The signatories of this letter have considered the return to normal conditions before the coronation unimaginable and have called for environmental care, an end to consumerism and a human focus on the real values of life (https://www.afp.com, 6 May 2020).

The change in human behavior is palpable in the time of the Corona. Patients, affected families, nurses, doctors, and even those who are not infected and only watch the depths of the tragedy have turned to God and spirituality. The despair of medical achievements and the search for a divine savior has turned into a round-the-clock whisper of hospital nurses and the general public. Atheism has flourished, believers have become more faithful, and non-believers are counting the moments waiting for the unseen hand of salvation. Mosques and churches; Despite the closure, they have become the starting point for human needs and appeals. Belief in the existence of a heavenly owner and confession of powerlessness over his power has flooded the dormitories of secularists and atheists. The power of science, in particular; Medical science is in doubt. The meaning of 
life and death, divine healing, and personal and social health have become more and more important.

For centuries, science and religion have competed not only for human happiness; But in war and strife. Science claims that through advanced tools, it has been able to cure diseases, increase life expectancy, provide human welfare facilities, and provide peace and happiness. Religion, in turn, considers man's happiness and well-being in individual perfection and self-cultivation, and prescribes theological prescriptions for man, which, if properly administered, will lead mankind through dangerous crises and dangerous stages. But, the fact is that this historical controversy has now been revived. Covid-19 has not only hampered the effectiveness of human scientific and technological tools; but traditional theology; Which has always spoken in denial of the effectiveness of science and its healing, has raised serious questions. Although, the reality of science and religion is inviolable, and these two souls have always been the savior and beacon of man. What its legitimacy is in doubt: Orientation and behavior of individuals, groups and communities claims. They need to provide convincing answers to desperate human questions. Proponents of scientific and positivist approaches that deny the intervention of supernatural and theological forces in human destiny and see the universe as nothing more than chemical interactions have not yet been able to curb disease or discover a cure for it, and thousands of corpses are buried daily.

Atheist and secular worldviews that for many years gave the wrong address to mankind; What do they have to say in this situation?! Do they still sing the song of emptiness and atheism? What is the way to save them from getting out of these difficult days?

In a world where most of its inhabitants are pursuing a quiet and carefree daily life and fleeing from the mystery of existence and gaining more awareness, atheism not only unties no knot in human work, but, it causes more turmoil and unrest.

Truly; Man, without reliance on God and without spiritual support; How and with what formula can he survive in the moments of life? Showing the empty sphere of heaven and earth from the Creator; For a human being exposed to a tiny mosquito or a five-gram virus, it is sheer folly and unforgivable betrayal.

Atheism is another export product of the developed countries of the West. The Western liberal system is allergic to God and religion, and is wary whenever there is talk of God's role in human life. From the point of view of Western material philosophy; The universe is like an old book whose cover has been torn off and disappeared. The first and last pages are also calligraphic and incomprehensible. What matters; The middle pages of this book are old. The human being who educates and delivers human society can only be defined in the materially impoverished world. It is not clear where it came from, what it came for and where its final destination is. That's mean; Man has no definite identity. Covid-19 shook the backbone of this absurd ideological and intellectual structure with its limbs. 
Putin's Russia and Erdogan's Turkey; Two non-Western countries whose bodies and hair have been blown by the western winds for years, in other words; They have tasted Western freedoms, they have longed to return to religion. The steps the two have taken since the COVID-19 pandemic to religiousize their community is worth considering. Adding belief in God, banning same-sex marriage, and resolving the Orthodox Church's concerns about marriage and child rearing were approved by 78 percent of Russians in the new Russian constitution, which was put to a referendum in June 2020. By turning the Hagia Sophia Museum into a mosque and reopening and offering prayers in it in July 2020, Turkey took another step in the direction of distancing itself from secularism, which was welcomed by a large number of its people.

A pandemic dealt a blow to humanism. He braked the arrogant and narcissistic man. Especially, the false self-confidence of Western man has been abandoned. The call to prayer spread through the streets of Germany and Spain, Trump announced the National Prayer Day, US government officials prayed in the White House, Quranic verses were posted on Dutch billboards, and prayers were offered in the streets of New York to ask for Christ's love and return. Man's need for a heavenly savior, the introduction of the meaning of the Day of Judgment and the importance of the health instructions of Islam in various societies, are some examples of the humility and strain of the coronated man against the divine destiny.

The element of "spiritual intelligence" acts as a safety valve in the crisis of meaning. Especially, in situations where man suffers from an ontological crisis. Enduring pressures and sudden crises that are beyond human comprehension requires a resilient and comforting factor in his mental body. Also; Accepting and coping with the unfortunate consequences of uncontrollable life events is facilitated despite spiritual intelligence. Understanding the divine presence acts like water on fire. Self-control, assertiveness, flexibility, hopefulness, and optimism about the future are components of spiritual intelligence that have a significant correlation with spiritual health. Studies show; Individuals and communities who have a clear understanding of the meaning and purpose of life are more immune to the shock of the Covid-19 pandemic and are protected from psychological collapse.

David Lynch, a well-known American director, talks about the need for "meditation" in coronary situations (Lynch, 2020). He sees meditation as a way to reduce stress, anxiety, hatred and revenge, and recommends that the world meditate daily to eliminate the negative energy of the coronavirus.

From one perspective, the behavior of the Corona virus is similar to that of the German fascists during the First and Second World Wars. The fascists sent people to gas chambers, incinerators, and concentration camps. Many of the victims had lost the meaning of life, and despair, suicide, and suicide had spread. The crisis in the meaning of life for the coronated human being is something like the experience of emptiness and meaninglessness during the world wars. Although; At that time, some people tried to find a meaning for their suffering, but 
many did not, and they welcomed death and ended their lives. Covid-19 behaves even more sophisticatedly than the fascists. All parts of the world have been turned into cemeteries. The ghost of death is circulating in all the alleys, streets and alleys of the world.

Nevertheless, in the corona world, doubts about the value and meaning of life have led to the birth of two human beings. One; Desperate and exhausted human beings who do not care about living and spend their days in despair and despair. Other one; $\mathrm{He}$ is a human being who has overcome doubts and found a new meaning for his life. The meaning that has led him to a higher and more valuable world. This type of human being, unlike the first one, has undergone a mental and psychological leap and has gained more knowledge of its existential capabilities and is hopefully looking to the future.

\section{Post-Corona Perspective}

The Covid-19 pandemic tested the human capabilities and capabilities of countries and changed many perceptions. The first European and American countries, which were considered the giants of power, progress and efficiency in the world public opinion, have become weak and powerless governments that can not cope with their own problems and, especially in this unknown situation, do not guarantee the survival of Crohn's patients. President Trump's illness and British Prime Minister Johnson as well; The mass graves in New York rightly revealed that the claim of global management is just a claim. Such countries, which have the most modern and advanced medical achievements and facilities, could not control the corona themselves and save the lives of their people. Now; How can they lead the world?! Instead; East and Asian countries such as Singapore, South Korea, China and Iran, with reasonable control and confrontation and to the best of their ability, were able to largely neutralize the Covid-19 threats.

Managing a global unit no longer makes sense under the pretext of globalization. Many countries have moved towards strengthening their foundations and are already turning to empowerment. Turning to nationalism leads to the formation of local and regional powers. The world is moving from a unipolar and bipolar state to a multipolar one, and one or more powerful countries are being unveiled anywhere in the world. Steven Walt, a professor at Harvard University and author of The American Foreign Policy Elite and the Declining Supremacy of the United States, believes that the Corona virus transmits power and influence from the West to the East. Besides that; According to him, the retreat of globalization and the emergence of local governments are other consequences. Also, Richards; "At least in the coming years, the Corona virus will lead to a look inside most governments," said the chairman of the Council on Foreign Relations. Governments have to be more inward-looking. I predict there will be more moves towards self-sufficiency

(https://www.foreignaffairs.com/articles/united-states/2020-06-05/protests-pand emic-world-watching).

A pandemic also tested the resilience and toughness of countries. Countries 
are more pragmatic than ever in investing more in their health care systems. Also; Investments are being revised for some businesses and institutions. Scientific and medical research and health services are considered more by governments than the Green Triangle and other costly and unprofitable sports that are merely short-term entertainment. Communities behave more economically and profitably. Football, cinema, music concerts, tours, and related activities and occupations have flourished, and the trend will continue. Three groups: 1) Doctors 2) Science researchers and 3) Enlightenment are in the spotlight. Doctors are doubly important and popular as saviors of body and soul. Scholars of scientific trends are increasingly favored by governments as explorers of new ideas and possibilities. Genuine and horizon-oriented intellectuals must be able to show a clear and rational view of present and future relations in the near and distant future and provide plausible answers, analyzes, and solutions to human questions.

In the meantime; First and second world countries are more vulnerable than third world countries. The element of emotion, empathy and participation in developing countries always neutralizes threats and turns them into opportunities. Iran; A country that has reduced its economy from dependence on oil in recent years and enjoys the psychological factor of collective cooperation in crises, which is a privileged social asset, is more likely to overcome the Covid-19 crisis and its aftermath. Conversely, The First World, due to its complex structures and cultural and social liberalism, global interventions, the existence of multinational corporations, free trade, the World Bank, the International Monetary Fund, the World Health Organization and the like, has taken on additional responsibilities and must experience several crises at the same time. And manage. Second and third world countries, on the other hand, are less vulnerable to political and economic fragility due to the existence of security-oriented and authoritarian governments. Why so, the government is reacting quickly and self-regulating to the problems and lack of educational and health facilities, security and prevention of chaos.

\subsection{Three Types of Society}

In Pasacrona, three types of society are revealed that function differently from the cognitive, behavioral, social and lifestyle economics (Abdolmalaki, 2021):

\subsubsection{Depressed and Helpless Communities}

The people of these societies, for psychological and cultural reasons, do not have the expected ability to adapt to the new world. In best situation, they will show minimal compatibility and coping. These societies have had poor economic and social capital from the beginning; they will become weaker. Very low levels of national self-esteem and social helplessness prevent them from being motivated and motivated to progress and develop. They remain grounded and there is no definite time for their recovery and self-discovery. India, Afghanistan and parts of the African continent fall into this category. 


\subsubsection{Collected Countries}

They could not even imagine being struck by a very small virus, having their spine crushed, and losing their national and international prestige in a very short period of time. These kinds of societies and their governments, which have constantly shown their sense of superiority and invincibility to others, will suffer double damage due to shock and confusion. They face a failure of national and political self-confidence and a negative self-image. Although, they try not to bring this fall on themselves and keep their face red with so-called slaps. The United States, Canada, Italy, Spain, Britain, and Turkey are among those societies that will feel like a nightmare to coexist for years like a nightmare.

\subsubsection{Tough and Resilient Countries}

Who have strong material, spiritual and human capital; Have the ability to recover quickly. With a short pause, they adapt to the ups and downs of the post-Corona world. Creativity, innovation, dynamism and national empathy are rooted in them. They are constantly producing new patterns and styles of economics and life. Iran, South Korea, Japan and Singapore, and perhaps China, fall into this category. In the meantime; Iranian society due to the spirit of cooperation and national cooperation in crises; It works uniquely.

\subsection{Postcoronian States}

After the end of the Covid-19 Pandemic, governments and states are categorized into three types in terms of behavioral model:

1) Government/Hobbesian government-bandit 2) Government/democratic government-cooperative axis 3) Inefficient government/government-traitor.

\subsubsection{Hobbesian-Bandit}

Who take an authoritarian and police approach to control and manage the unsettled situation of their property and nation. Due to poverty and sudden deprivation, the government is no longer able to respond to and assess the needs of society. Meanwhile; People's expectations are high. Dissatisfaction is growing day by day and the street riots of the hungry leave no choice but to suppress these governments. Some G7 countries have been suddenly hit by rising unemployment, high inflation, declining GDP and negative economic growth due to a period of significant economic development and abundance. Britain has re-entered the recession 11 years after its last recession. In Britain, national debt has surpassed GDP. These successive economic shocks have the long-term dire consequences that these governments not only have no choice but to suppress dissidents at home, but are forced to resort to international banditry to feed their nations. It seems that these states have implemented Hobbes' thesis that "man is a wolf is man" as the law of governance.

\subsubsection{People-Based Cooperation}

In these countries, because from the beginning the level of facilities and expectations of society have been close to each other and there is a two-way interaction 
between the people and the government, overcoming the status quo, although it seems difficult, is possible with the least momentum and conflict. Realistic understanding and emotional resilience of these societies act as a catalyst, facilitating timely adaptation to the demands of the post-Corona world. Iran is one of the rarest countries with a strong element of religion, cooperation and leadership. When the knife reaches the bone, it is a potion of three elements similar to the Christian soul; He raises the dead. The unwavering cooperation and forgiveness of the Iranian people in helping the needy in response to the Supreme Leader's request for "faithful assistance" is an event rarely found in any other country. Co-operative governments will be safe from corona and post-corona damage and will suffer the least damage. Why so; Spiritual capital flows through their individual and collective institutions to neutralize threats, and so on; It turns into an opportunity. Empathetic and reciprocal understanding motivates the government to have the air of its citizens.

\subsubsection{Ineffective-Traitor}

These kinds of governments and their societies of all dimensions and situations are in structural and chronic poverty. Economic, political, cultural, intellectual, and defense-security poverty lives with them as a twin and does not exploit them. They are backward for cultural and historical reasons and suffer from learned social helplessness. Like an aqueduct that has no water and must be periodically injected with a water tanker. Government in such countries is worse than usual; It moves towards more inefficiency and heavier losses. In parts of Africa, rulers, politicians and statesmen are mired in financial corruption and structural injustice, dragging their country to the brink. The inefficiency and betrayal of the rulers in the long run has made these kinds of governments prone to collapse. In post-Corona, this inefficiency and betrayal will intensify due to the influence of authoritarian and bandit governments because; These incompetent rulers offer their national interests to oppressive and predatory governments to ensure their survival.

\section{Discussion and Conclusion}

What we want and what we do not want; the corona pandemic has transformed our mental and real world, and it will change even more. Some of us still do not understand the new situation. We continue on the previous circuit and hope Covid-19 is a dream or a nightmare. But the reality is something else. Our world has undergone fundamental changes. Major economic and industrial bankruptcies, floods of unemployed people, changing attitudes in the education system and social services, online and virtualization of education, shopping and even communication, class divisions and social crises, and the experience of loneliness and isolation are all events that we inevitably face. We are coping with it. Psychologists consider intelligence, rational understanding of conditions and adaptation to the environment as signs of human intelligence. So it is necessary to behave both logically and realistically and to coexist with the new conditions. 
This, a new form of our life. Running away from the stage only proves that we are cowards. War is also a sign of anesthesia.

Although many of us consider corona to be a great threat and danger; But its opportunities are commendable. The corona was a wake-up call for us to come to our senses; Reconsider our behaviors and lifestyles. Avoid consumption. Know more about what we value. Respect the privacy of others. Get more knowledge and information about health issues. Be more sensitive to our health and those around us. Family members spend more time together and enjoy being together. Also, paying attention to reading and books, optimal and purposeful use of Internet technology, reducing traffic and air pollution are among the rare blessings of Corona.

Undoubtedly, in addition to the economic and social effects of corona, the psychological damage caused by the experience of corona crisis, including social isolation, paranoia, depression, anxiety and unfinished grief caused by the death of loved ones, is very pervasive and devastating. In my opinion, the new era is an era of mental crisis in which governments and nations need to find a solution. It is suggested that governments should reduce the financial and psychological pressures through rational planning and policy-making, increase psychological literacy among the people, and show greater empathy for the people of the community.

\section{Conflicts of Interest}

The author declares no conflicts of interest regarding the publication of this paper.

\section{References}

Abdolmalaki, S. (2021). The Secret of a Pandemic (How Covid-19 Overturned Human Beliefs and Behaviors?) A Critical Approach. Golden Authors Publications.

Babroo, E. (2020, July 13). I Feel Like I'm Sinking into the Earth: Mothers Alone in the Corona (Translated by Babak Tahmasebi). The New Yorker, Humanities Translator Website.

Lynch, D. (2020, July 4). David Lynch Tells the Secret of Meditation and Its Relationship with Happiness and Creativity. Hamshahri Online.

Shabani, M. (2020, April 6). Corona Crisis and Concerns about Increasing Violence against Women in Turkey. Aso Website. 